
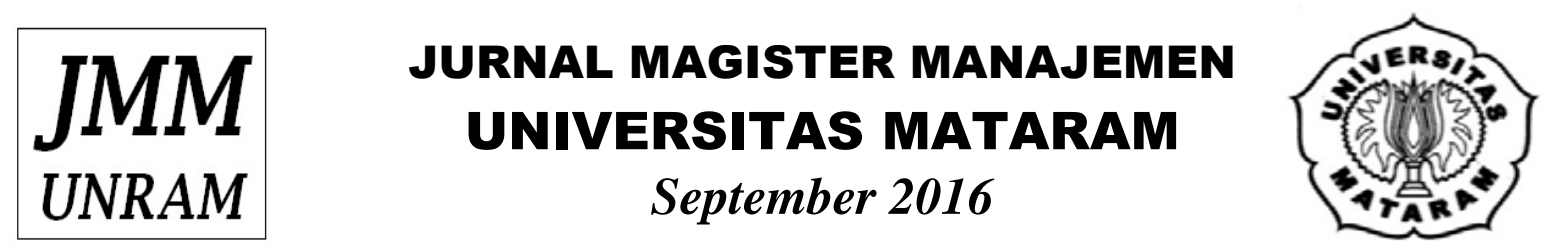

\title{
PENGARUH Governace GOOD CORPORATE TERHADAP NILAI PERUSAHAAN DENGAN RISIKO KREDIT SEBAGAI variabel intervening \\ (Pada Perusahaan Perbankan Yang Terdaftar Di BEI)
}

\author{
Wayan Putri Lawinataliani ${ }^{1}$ \\ Ni Ketut Surasni ${ }^{2}$ \\ I Nyoman Nugraha AP2
}

\begin{abstract}
This research is aimed at determining the direct and indirect effect of good corporate governance on the value of company with the credit risk as the intervening variable analyzing the financial performance of the bank registered in Indonesia Stock Exchange during the period of 2011-2013. Good Corporate Governance is examined with the composite of GCG which is the self assessment of the bank. The credit risk is examined with the Non Performing Loan (NPL). The value of the company is examined with the Price Book Value (PBV). The number of the population of this research is 41 companies from which 22 samples were selected through purposive sampling. The analysis in this research is the path analysis to obtain the whole description of the correlation between one and another variable. The research showed that GCG has effect on the credit risk, while the credit risk has the effect on the company value. Thus this means that credit risk can be the intervening variable between GCG and the company value.
\end{abstract}

Key Words : GCG, NPL dan PBV

\section{PENDAHULUAN}

Pada dunia perbankan, nilai perusahaan menjadi perhatian penting bagi bank yang merupakan perusahaan yang menjalankan fungsi intermediasi atas dana yang diterima nasabah. Kegagalan bank dalam menjaga nilai perusahaannya akan menyebabkan kurangnya kepercayaan nasabah, sehingga dana yang dikelola untuk mendapatkan keuntungan pun berkurang (Setyawan, 2012).

Sinyal positif tentang perusahaan di masa mendatang akan terjadi jika ada peluang investasi sehingga akan meningkatkan nilai perusahaan. Salah satu rasio yang banyak digunakan dalam mengambil keputusan investasi adalah rasio harga saham terhadap nilai buku perusahaan atau Price Book Value (PBV). PBV adalah nilai aset perusahaan dibagi jumlah saham yang diterbitkan perusahaan, dengan kata lain nilai 


\section{JURNAL MAGISTER MANAJEMEN UNIVERSITAS MATARAM \\ September 2016}

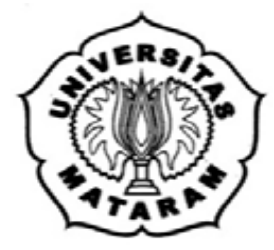

buku saham merupakan nilai wajar dari saham emiten tersebut, sementara harga saham bisa dipengaruhi oleh banyak faktor.

Dalam pengambilan suatu keputusan, investor dan calon investor membutuhkan suatu informasi yang lengkap, akurat dan tepat waktu sehingga hasil yang diperoleh sesuai dengan harapan (Sembiring, 2005). Informasi tersebut dapat bersifat non keuangan, dimana informasi non keuangan ini dapat berpengaruh terhadap nilai suatu perusahaan. Salah satu informasi non keuangan yang mempengaruhi nilai perusahaan adalah Good Corporate Governance (GCG). Menurut (Ali, 2006:334) GCG adalah sistem yang digunakan dalam mengarahkan dan mengendalikan kegiatan bisnis perusahaan.

Bank merupakan lembaga keuangan yang dihadapkan pada banyak risiko, dengan menjual kepercayaan kepada para nasabah, investor dan pemegang saham. Sehingga, bank diharuskan menyampaikan laporan keuangannya secara transparan (Aryani, 2012). Demi menjaga kelangsungan hal tersebut, maka kemampuan bank dalam mengelola kinerja dan tata kelola perusahaan yang baik akan menjadi pertimbangan investor dalam menanamkan modalnya, sehingga tercermin melalui nilai perusahaannya.

Manajemen risiko yang efektif, khususnya untuk bank yang besar dan beroperasi pada pasar yang terderegulasi dan kompetitif memerlukan proses yang formal. Pengelolaan risiko menjadi hal yang penting bagi bank dalam melaksanakan bisnis yang semakin kompleks dengan terukurnya tingkat risiko. Untuk mencapai tujuan di atas, Bank Indonesia mengeluarkan Surat Edaran Bank Indonesia No. 13/23/DPNP tanggal 25 Oktober 2011 tentang penerapan manajemen risiko bagi bank umum dengan perlu dibangunnya kesadaran dan budaya manajemen risiko terpadu dan difokuskan pada efektivitas penerapan tata kelola dan kerangka kerja manajemen risiko.

Dalam menjalankan bisnis, perbankan dihadapi dengan banyak risiko diantaranya risiko kredit, risiko pasar dan risiko operasional (Ali, 2006:397). Aktivitas kredit merupakan hal yang sangat penting pada sektor perbankan, karena tanpa disadari aktivitas perkreditan menjadi tulang punggung dari kegiatan utama perbankan. Risiko kredit timbul dikarenakan suatu keadaan dimana nasabah sudah tidak sanggup membayar sebagian atau seluruh kewajibannya kepada bank seperti yang telah diperjanjikan sehingga terjadi kredit bermasalah atau macet. Risiko kredit dapat diukur dengan rasio Non Performing Loan (NPL), rasio ini menunjukkan kemampuan manajemen suatu bank dalam mengelola kredit bermasalah, artinya semakin tinggi nilai rasio NPL maka akan semakin rendah kualitas kredit dan tingkat pengembalian kredit macet, sehingga menyebabkan kerugian bagi bank. Menjaga nilai perusahaan yang tetap baik dan menghindarkannya dari risiko merupakan keharusan bagi manajemen perusahaan, dimana pengelolaan risiko kredit yang baik dapat meningkatkan nilai perusahaan dengan signifikan. Pemaparan tersebut menunjukkan bahwa penerapan GCG yang baik dengan kontrol yang ketat terhadap pengelolaan 


\section{JURNAL MAGISTER MANAJEMEN UNIVERSITAS MATARAM \\ September 2016}

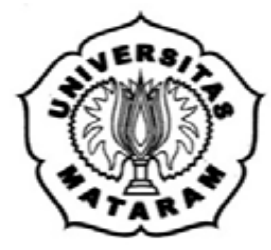

risiko kredit atau kredit bermasalah maka bank akan mendapatkan keuntungan yang lebih besar dan ditunjukkan melalui nilai perusahaannya.

\section{TUJUAN PENELITIAN}

a. Untuk menganalisis pengaruh Good Corporate Governance terhadap nilai perusahaan

b. Untuk menganalisis pengaruh Good Corporate Governance terhadap risiko kredit

c. Untuk menganalisis pengaruh risiko kredit terhadap nilai perusahaan

\section{LANDASAN TEORI}

\subsection{Teori Keagenan}

Menurut Jensen dan Meckling (dalam Kawatu, 2009:407), teori agensi menjelaskan tentang hubungan kontraktual antara pihak yang mendelegasikan keputusan tertentu (principal/pemilik/pemegang saham) dengan pihak yang menerima pendelegasian tersebut (agen/manajemen). Terjadinya konflik kepentingan antara pemilik dan agen karena kemungkinan agen bertindak tidak sesuai dengan kepentingan principal, sehingga memicu biaya keagenan (agency cost).

Sebagai pengelola perusahaan, manajer perusahaan tentu akan lebih banyak mengetahui informasi internal dan prospek perusahaan di masa yang akan datang dibandingkan pemilik (pemegang saham). Oleh karena itu, manajer sudah seharusnya selalu memberikan sinyal mengenai kondisi perusahaan kepada pemilik. Sinyal yang dapat diberikan oleh manajer yakni melalui pengungkapan informasi akuntansi seperti laporan keuangan. Laporan keuangan merupakan hal yang sangat penting bagi para pengguna eksternal terutama karena kelompok ini berada dalam kondisi yang paling besar ketidakpastiannya (Ali, 2002). Adanya ketidakseimbangan penguasaan informasi ini akan memicu munculnya kondisi yang disebut sebagai asimetri informasi (information asymmetry). Dengan adanya asimetri informasi antara manajemen (agent) dengan pemilik (principal) akan memberi kesempatan kepada manajer untuk melakukan manajemen laba (earnings management) sehingga akan menyesatkan pemilik (pemegang saham) mengenai kinerja ekonomi perusahaan.

Corporate governance yang merupakan konsep yang didasarkan pada teori keagenan, diharapkan bisa berfungsi sebagai alat untuk memberikan keyakinan kepada para investor bahwa mereka akan menerima return atas dana yang telah mereka investasikan. Corporate governance sangat berkaitan dengan bagaimana membuat para investor yakin bahwa manajer akan memberikan keuntungan bagi mereka, yakin bahwa manajer tidak akan mencuri/menggelapkan atau menginvestasikan ke dalam proyekproyek yang tidak menguntungkan berkaitan dengan dana/kapital yang telah ditanamkan oleh investor. Selain itu Corporate Governance juga berkaitan dengan 


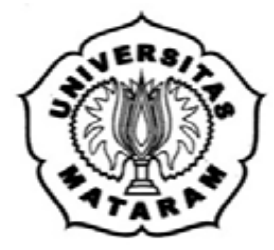

bagaimana para investor mengontrol para manajer. Dengan kata lain, yakni corporate governance diharapkan akan dapat berfungsi untuk menekan atau menurunkan biaya keagenan (agency cost).

\subsection{Teori Signal}

Menurut Arifin (2005:11) teori sinyal (signaling theory) merupakan teori yang dikembangkan untuk mengetahui kemungkinan bahwa informasi yang berkaitan dengan kondisi dan prospek perusahaan dimasa depan lebih banyak diketahui oleh orang dalam (insiders) perusahaan dari pada para investor yang merupakan orang luar perusahaan.

Signaling Theory merupakan suatu tindakan perusahaan dalam memberikan sinyal kepada para pengguna laporan keuangan dan untuk memberikan petunjuk dan informasi mengenai cara pandang manajemen terhadap prospek perusahaan. Perusahaan dengan prospek yang baik akan memberikan sinyal yang baik untuk para investor dalam pengambilan keputusan investasi, keputusan kredit ataupun keputusan lainnya yang sejenis. Sinyal dapat digolongkan menjadi dua yaitu sinyal yang berupa good news, seperti kinerja perusahaan perbankkan yang selalu mengalami peningkatan di setiap tahunnya dan sinyal berupa bad news, seperti kinerja perusahaan perbankkan yang selalu mengalami penurunan di setiap tahunnya.

\subsection{Stewardship Theory}

Stewardship theory dibangun di atas asumsi filosofis mengenai sifat manusia yakni bahwa manusia pada hakekatnya dapat dipercaya, mampu bertindak dengan penuh tanggung jawab, memiliki integritas dan kejujuran terhadap pihak lain. Inilah yang tersirat dalam hubungan fidusia yang dikehendaki para pemegang saham. Dengan kata lain, stewardship theory memandang manajemen sebagai suatu hal yang dapat dipercaya untuk bertindak dengan sebaik-baiknya bagi kepentingan publik maupun stakeholder (Kaihatu, 2006).

\subsection{Nilai Perusahaan}

Nilai perusahaan merupakan kondisi tertentu yang telah dicapai oleh suatu perusahaan sebagai gambaran dari kepercayaan masyarakat terhadap perusahaan setelah melalui suatu proses kegiatan selama beberapa tahun, yaitu sejak perusahaan tersebut didirikan sampai dengan saat ini. Nilai perusahaan yang tinggi menjadi keinginan para pemilik perusahaan, sebab dengan nilai yang tinggi menunjukkan kemakmuran pemegang saham juga tinggi (Kusumadilaga, 2010). 


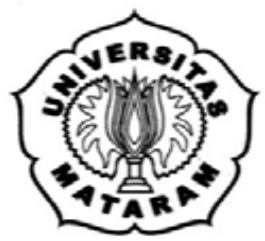

Secara umum banyak metode dan teknik yang telah dikembangkan dalam penilaian perusahaan diantaranya adalah: a) pendekatan laba antara lain metode rasio tingkat laba atau price earning ratio metode kapitalisasi; b) pendekatan arus kas antara lain metode diskonto arus kas; c) pendekatan dividen antara lain pertumbuhan dividen; d) pendekatan aktiva antara lain metode penilaian aktiva; e) pendekatan harga saham; f) pendekatan economic value added (Suharli, 2006).

Nilai perusahaan dalam penelitian ini didefinisikan sebagai nilai pasar dengan pendekatan harga saham. Nilai perusahaan yang dibentuk melalui indikator nilai pasar saham sangat dipengaruhi oleh peluang-peluang investasi. Adanya peluang investasi dapat memberikan sinyal positif tentang pertumbuhan perusahaan dimasa yang akan datang, sehingga dapat meningkatkan nilai perusahaan. Penelitian ini menggunakan PBV sebagai proksi dari nilai perusahaan. Putri (2013) menyatakan bahwa price to book value merupakan perbandingan antara harga pasar saham terhadap nilai buku per lembar saham, semakin tinggi nilai price to book value maka semakin tinggi pula harga saham suatu perusahaan. Harga pasar dari suatu saham yang semakin tinggi, maka capital gain (actual return) juga akan semakin tinggi. Perusahaan yang kinerjanya baik biasanya memiliki nilai rasio PBV diatas satu, hal ini menunjukkan bahwa nilai pasar saham lebih tinggi dari nilai bukunya (Putri, 2013). PBV biasanya juga digunakan untuk mengevaluasi saham-saham dalam industri perbankan karena sebagian besar aset perbankkan umumnya sudah mencerminkan nilai pasar saat ini. . PBV dapat dirumuskan sebagai berikut:

$$
\begin{gathered}
\text { Price to Book Value }=\frac{\text { harga pasar saham per lembar }}{\text { nilai buku saham per lembar }} \\
\text { Sumber }: \text { Hasan (2011) }
\end{gathered}
$$

\subsection{Risiko Kredit}

Menurut Pasal 1 PBI No.11/25//PBI/2009, risiko kredit adalah risiko akibat kegagalan debitur dan/atau pihak lain dalam memenuhi kewajiban kepada bank. Risiko kredit pada umumnya terdapat pada seluruh aktivitas bank yang kinerjanya bergantung pada kinerja pihak lawan (counterparty), penerbit (issuer) atau kinerja peminjam dana (borrower). Risiko kredit juga dapat diakibatkan oleh terkonsentrasinya penyediaan dana pada debitur, wilayah geografis, produk, jenis pembiayaan atau lapangan usaha tertentu (SE BI No.13/24/DPNP/2011).

Risiko kredit juga dapat diakibatkan oleh terkonsentrasinya penyediaan dana pada debitur, wilayah geografis, produk, jenis pembiayaan atau lapangan usaha tertentu. Risiko ini lazim disebut Risiko Konsentrasi Kredit dan wajib diperhitungkan pula dalam penilaian Risiko inheren. Dalam menilai Risiko inheren atas Risiko Kredit, parameter/indikator yang digunakan adalah: (i) komposisi portofolio aset dan tingkat 


\section{JURNAL MAGISTER MANAJEMEN UNIVERSITAS MATARAM \\ September 2016}

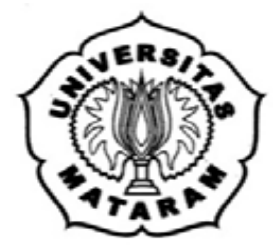

konsentrasi; (ii) kualitas penyediaan dana dan kecukupan pencadangan; (iii) strategi penyediaan dana dan sumber timbulnya penyediaan dana; dan (iv) faktor eksternal.

Dalam penelitian ini digunakan rasio Non Performing Loan (NPL) dalam menunjukkan kemampuan manajemen bank dalam mengelola kredit bermasalah yang diberikan bank tersebut. Menurut Kasmir (2010:228) Credit Risk Ratio merupakan rasio yang digunakan untuk mengukur risiko terhadap kredit yang disalurkan dengan membandingkan kredit macet dengan jumlah kredit yang disalurkan. Semakin tinggi rasio NPL maka akan memperbesar biaya operasional yang berpotensi terhadap kerugian suatu bank akibat jumlah kredit yang bermasalah semakin besar sehingga berpengaruh terhadap kualitas kesehatan bank.

\subsection{Good Corporate Governance}

Forum for Corporate Governance in Indonesia mendefinisikan GCG sebagai seperangkat aturan yang menetapkan hubungan antara pemegang saham pengurus, pihak kreditur, pemerintah, karyawan serta para pemegang kepentingan intern dan ekstern lainnya sehubungan dengan hak-hak dan kewajiban mereka (Arifin, 2005:67). Setiap Bank harus memastikan bahwa asas GCG diterapkan pada setiap aspek bisnis dan di seluruh jajaran bank. Asas GCG yang harus dipastikan pelaksanaanya meliputi transparansi, akuntabilitas, responsibilitas, indepedensi serta kewajaran dan kesetaraan. Asas-asas GCG diperlukan untuk mencapai kesinambungan usaha (sustainability) bank dengan memperhatikan kepentingan pemegang saham, nasabah serta pemangku kepentingan lainnya.

Prinsip-prinsip GCG dan fokus penilaian terhadap pelaksanaan prinsip-prinsip GCG mengacu pada ketentuan Bank Indonesia mengenai Good Corporate Governance bagi bank umum dengan memperhatikan karakteristik dan kompleksitas usaha (PBI No.13/1/2011 pasal 7 ayat 2). Faktor-faktor penilaian tingkat kesehatan Bank ditinjau dari asas penerapan Good Corporate Governance pada perbankkan umum adalah :

1. Transparansi

2. Akuntabilitas

3. Tanggung Jawab

4. Independensi

5. Kewajaran

Indikator penilaian pada GCG yaitu menggunakan bobot penilaian berdasarkan nilai komposit dari ketetapan Bank Indonesia menurut PBI No. 13/ 1/ PBI/ 2011 Tentang Penilaian Tingkat Kesehatan Bank Umum. Self assessment GCG dilakukan dengan mengisi Kertas Kerja Self Assessment GCG yang telah ditetapkan, yang meliputi 11 (sebelas) Faktor Penilaian, dengan cara: 


\section{JURNAL MAGISTER MANAJEMEN \\ UNIVERSITAS MATARAM \\ September 2016}

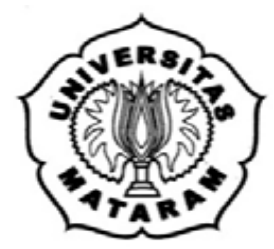

a. Menetapkan Nilai Peringkat per Faktor, dengan melakukan Analisis Self Assessment dengan cara membandingkan Tujuan dan Kriteria/Indikator yang telah ditetapkan dengan kondisi Bank yang sebenarnya.

b. Menetapkan nilai komposit hasil self assessment, dengan cara membobot seluruh faktor, menjumlahkannya dan selanjutnya memberikan predikat kompositnya. dalam penetapan predikat, perlu diperhatikan batasan berikut :

- Apabila dalam penilaian seluruh faktor terdapat faktor dengan nilai peringkat 5, maka predikat komposit tertinggi yang dapat dicapai bank adalah "cukup baik";

- Apabila dalam penilaian seluruh faktor terdapat faktor dengan nilai peringkat 4, maka predikat komposit tertinggi yang dapat dicapai bank adalah "baik".

4. KERANGKA KONSEPTUAL

a. Gambar Kerangka Konseptusl

Gambar 1. Kerangka Konseptual

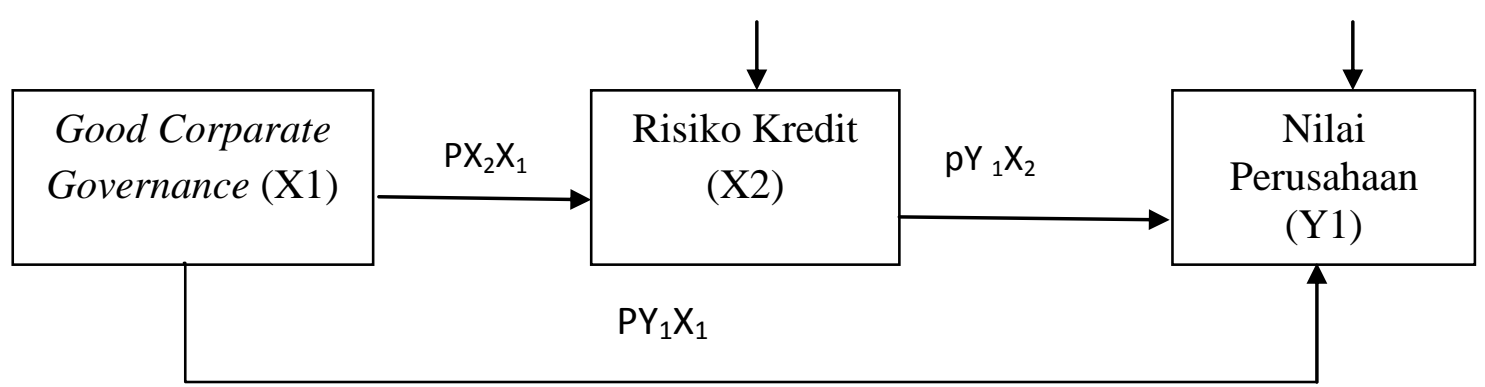

b. Hipotesis

H1 = Diduga GCG yang baik akan meningkatkan nilai perusahaan

H2 = Diduga GCG yang baik akan menurunkan risiko kredit

H3 = Diduga risiko kredit yang menurun akan meningkatkan nilai perusahaan

\section{METODE PENELITIAN}

\subsection{Jenis Penelitian, Populasi dan Sampel}

Jenis penelitian yang digunakan dalam penelitian ini adalah penelitian asosiatif (sebab-akibat). Populasi dalam penelitian ini adalah seluruh bank yang terdaftar di Bursa Efek Indonesia sebanyak 41 perusahaan. Adapun sampel yang diambil 


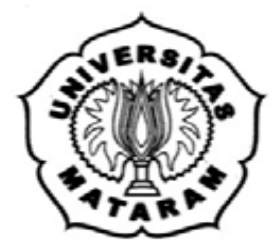

menggunakan teknik purposive sampling sehingga terpilihlah 22 perusahaan perbankan sebagai sampel penelitian.

\subsection{Analisis Jalur (Path Analysis)}

Analisis jalur (Path Analysis) digunakan untuk menganalisis pola hubungan kausal antar variabel dengan tujuan mengetahui pengaruh langsung dan tidak langsung secara serempak atau mandiri beberapa variabel penyebab terhadap sebuah variabel akibat (Muhidin dan Abdurahman, 2011:221).

Adapun langkah-langkah pengujian analisis jalur sebagai berikut:

1. Merumuskan hipotesis dan persamaan struktural

Langkah pertama dalam penelitian ini adalah membuat model dan rancangan penelitian, bila dikonversikan dalam bentuk persamaan struktural dan hipotesis

2. Uji asumsi klasik, uji asumsi klasik yang melandasi analisis jalur.

3. Menghitung koefisien jalur yang didasarkan pada koefisien regresi

a. Gambarkan diagram jalur lengkap dengan menentukan sub-sub strukturnya serta merumuskan persamaan strukturalnya sesuai dengan hipotesis.

b. Menghitung koefisien regresi untuk struktur yang telah dirumuskan secara keseluruhan, untuk menguji apakah perhitungan secara individual dapat dilakukan.

Persamaan regresi $: Y=a+b_{1} x_{1}+\ldots \ldots . .+e$

4. Menghitung koefisien jalur secara individu

5. Interpretasi hasil analisis

6.

6. HASIL PENELITIAN

6.1 Hasil Uji Asumsi Klasik

Tabel 1. Uji Asumsi Klasik

\begin{tabular}{|l|l|}
\hline Asumsi Klasik & Keterangan \\
\hline Normalitas & Lulus Uji Asumsi Klasik \\
\hline Heteroskedastisitas & Lulus Uji Asumsi Klasik \\
\hline Autokorelasi & Lulus Uji Asumsi Klasik \\
\hline
\end{tabular}

Sumber : Data primer diolah 


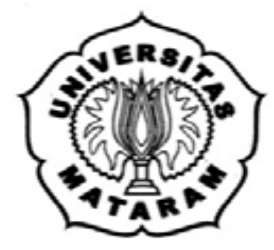

\subsection{Analisa Jalur}

Tabel 2. Koefisien Analisa Jalur Pengaruh Langsung dan Tidak Langsung

\begin{tabular}{|l|l|l|l|l|}
\hline Analisa Jalur & $\begin{array}{l}\text { Koefisien } \\
\text { Jalur }\end{array}$ & Probabilitas & Keterangan & $\begin{array}{l}\text { Simpulan } \\
\text { Hipotesis }\end{array}$ \\
\hline GCG $\rightarrow$ NPL & $\mathbf{0 , 5 0 0}$ & 0,005 & Signifikan & H1 Diterima \\
\hline NPL $\rightarrow$ PBV & $-0,245$ & 0,000 & Signifikan & H2 Diterima \\
\hline GCG $\rightarrow$ PBV & $-0,345$ & 0,047 & Signifikan & H3 Diterima \\
\hline
\end{tabular}

Sumber : Data primer diolah

Berdasarkan tabel 3 di atas dapat terlihat bahwa Pengaruh antara Good Corporate Governance (X1) tehadap nilai perusahaan (Y1) mempunyai nilai koefisien jalur (beta) sebesar -0,345 dengan nilai signifikansi sebesar 0,005 lebih kecil dari nilai probabilitas yang distandarkan sebesar 0,05.

Pengaruh antara Good Corporate Governance (X1) tehadap risiko kredit (X2) mempunyai nilai koefisien jalur (beta) sebesar nilai koefisien jalur sebesar 0,500 dengan nilai signifikansi sebesar 0,000 lebih kecil dari nilai probabilitas yang distandarkan sebesar 0,05.

Pengaruh antara risiko kredit (X2) tehadap nilai perusahaan (Y1) mempunyai nilai koefisien jalur (beta) sebesar nilai koefisien jalur sebesar $\quad-0,245$ dengan nilai signifikansi sebesar 0,047 lebih kecil dari nilai probabilitas yang distandarkan sebesar 0,05 .

\section{PEMBAHASAN}

a. Pengaruh Langsung Good Corporate Governance (X1) Terhadap Nilai Perusahaan (Y1)

Hasil ini menunjukkan bahwa Good Corporate Governance yang diukur dengan nilai komposit Good Corporate Governanace berpengaruh terhadap nilai perusahaan yang diukur dengan Price Book Value yang sesuai dengan hipotesis bahwa Good Corporate Governanace yang baik akan meningkatkan nilai perusahaan. Nilai komposit yang tinggi artinya peringkat komposit bank akan semakin besar yang memiliki makna bahwa penerapan Good Corporate Governance pada bank bersangkutan semakin buruk begitu pula sebaliknya nilai komposit yang rendah asrtinya peringkat komposit bank akan semakin rendah yang memiliki makna bahwa penerapan Good Corporate Governanace pada bank bersangkutan semakin baik.

Menurut SK BI No.9/12/DPNP Tahun 2011, semakin kecil skor GCG maka kualitas manajemen dalam menjalankan operasional bank sangat baik sehingga bisa mendapat laba, hal ini berarti semakin baik kinerja GCG maka investor akan merespon melalui kenaikan nilai perusahaan. Dengan demikian hasil penelitian ini 


\section{JURNAL MAGISTER MANAJEMEN UNIVERSITAS MATARAM \\ September 2016}

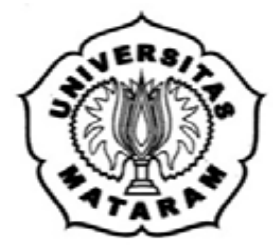

sesuai dengan teori bahwa nilai komposit yang tinggi maka Good Corporate Governance semakin buruk dan nilai perusahaan bank juga semakin buruk begitu pula sebaliknya. Hasil penelitian yang menunjukkan bahwa Good Corporate Governance berpengaruh terhadap nilai perusahaan, hal ini konsisten dengan penelitian Retno dan Denies (2012) yang menunjukkan bahwa Good Corporate Governance berpengaruh terhadap nilai perusahaan. Ini menunjukkan bahwa investor bersedia memberikan premium lebih kepada perusahaan yang memberikan tranparansi atas pelaksanaan Good Corporate Governance dalam laporan tahunan mereka.

\section{b. Pengaruh Langsung Good Corporate Governance (X1) Terhadap Risiko Kredit (X2)}

Hasil ini menunjukkan bahwa Good Corporate Governance yang diukur dengan nilai komposit Good Corporate Governanace berpengaruh terhadap risiko kredit yang diukur dengan Non Performing Loan (NPL) dan sesuai dengan hipotesis bahwa Good Corporate Governanace baik akan menurunkan risiko kredit. Nilai komposit Good Corporate Governance tinggi memiliki makna bahwa penerapan Good Corporate Governanace semakin buruk maka risiko kredit yang diukur dengan Non Performing Loan (NPL) bank akan tinggi, begitu pula sebaliknya. Nilai komposit yang tinggi artinya peringkat komposit bank akan semakin besar yang memiliki makna bahwa penerapan Good Corporate Governance pada bank bersangkutan semakin buruk. Sedangkan nilai Non Performing Loan (NPL) yang tinggi memiliki makna bahwa kredit bermasalah yang terdapat pada bank bersangkutan semakin tinggi.

Stewardship theory menjelaskan apabila terjadi penyalahgunaan corporate governance yang dilakukan manajemen maka akan menyebabkan penyimpangan kinerja perusahaan yang negatif dan dapat merugikan para pemegang saham, kreditur dan pihak-pihak yang terkait. Seperti yang ditunjukkan dalam penelitan (Jensen \& Meckling, 1976; Barnhart S. W., 1998) dimana semakin besar proporsi komisaris indepen maka semakin tinggi independensi dan efektivitas corporate board, sehingga manajemen risiko yang salah satunya terdapat risiko kredit menjadi semakin efektif dan baik. Dengan demikian hasil penelitian ini sesuai dengan teori bahwa nilai komposit yang tinggi maka Good Corporate Governance semakin buruk dan risiko kredit bank juga semakin buruk begitu pula sebaliknya.

Hasil penelitian yang menunjukkan bahwa Good Corporate Governance berpengaruh terhadap risiko kredit, hal ini konsisten dengan penelitian Permatasari dan Novitasary (2014) yang menunjukkan bahwa penerapan Good Corporate Governance berpengaruh positif terhadap manajemen risiko yang diukur dengan Non Performing Loan (NPL). Ini membuktikan bahwa bank dengan penerapan Good Corporate Governance yang baik dapat meminimalkan risiko kredit bermasalah 


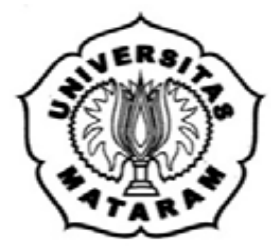

(macet) yang terdapat pada bank. Hal ini dikarenakan risiko kredit masuk dalam penilaian manajemen risiko dan manajemen risiko merupakan salah satu poin penilaian dalam kertas kerja self assessment sehingga apabila penerapan Good Corporate Governance pada bank baik, maka risiko kredit juga akan baik.

\section{c. Pengaruh Langsung Risiko Kredit (X2) Terhadap Nilai Perusahaan (Y1)}

Hasil ini menunjukkan bahwa risiko kredit yang diukur dengan nilai Non Performing Loan (NPL) berpengaruh terhadap nilai perusahaan yang diukur dengan Price Book Value (PBV) yang sesuai hipotesis bahwa risiko kredit yang menurun akan meningkatkan nilai perusahaan. Hal ini dapat diartikan bahwa apabila nilai Non Performing Loan (NPL) tinggi maka Price Book Value (PBV) bank akan rendah, begitu pula sebaliknya. Non Performing Loan (NPL) yang tinggi artinya kredit bermasalah (macet) yang dihadapi bank semakin tinggi atau buruk. Sedangkan nilai Price Book Value (PBV) yang tinggi memiliki makna bahwa nilai perusahaan yang terdapat pada bank bersangkutan semakin tinggi atau baik.

Teori sinyal pun menjelaskan pentingnya risiko kredit dalam mempengaruhi nilai perusahaan bank. Sinyal yang baik dapat berarti bank mampu memberikan kredit pada nasabah dengan risiko yang kecil. Semakin besar kredit yang diberikan, semakin banyak bank memperoleh pendapatan bunga sehingga nilai perusahaan pun akan meningkat. Dengan demikian hasil penelitian ini sesuai dengan teori bahwa Non Performing Loan (NPL) yang tinggi maka Price Book Value (PBV) bank semakin rendah atau buruk. Hasil penelitian juga menunjukkan bahwa risiko kredit berpengaruh terhadap nilai perusahaan, hal ini konsisten dengan penelitian Ratih (2011) yang menunjukkan bahwa risiko kredit yang diukur dengan Non Performing Loan (NPL) memiliki perngaruh yang negatif terhadap kinerja perusahaan. Hal ini berarti dengan adanya penurunan persentase risiko kredit maka akan meningkatkan profitabilitas bank sehingga laba perusahaan yang meningkat secara langsung akan berdampak pada peningkatan nilai saham perusahaan.

\section{d. Pengaruh Tidak Langsung Good Corporate Governance (X1) Terhadap Nilai Perusahaan (Y1) Melalui Risiko Kredit (X2)}

Dalam penelitian ini, terdapat pengaruh tidak langsung antara variabel Good Corporate Governance terhadap nilai perusahaan melalui risiko kredit. Dari hasil analisa tersebut, maka untuk menghitung pengaruh tidak langsung tersebut adalah sebagai berikut :

- Good Corporate Governance terhadap nilai perusahaan melalui risiko kredit $0,500 X-0,245=-0,1225$ 


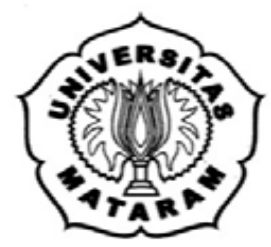

Dari perhitungan tersebut, memberikan arti bahwa terdapat pengaruh yang tidak langsung antara variabel Good Corporate Governance yang diukur dengan nilai komposit Good Corporate Governance terhadap nilai perusahaan yang diukur dengan Price Book Value (PBV) melalui risiko kredit Non Performing Loan (NPL) memiliki nilai koefisien jalur sebesar $\quad-0,1225$. Perbandingan pengaruh tidak langsung Good Corporate Governance terhadap nilai perusahaan melalui risiko kredit dengan pengaruh langsung Good Corporate Governance terhadap nilai perusahaan diperoleh hasil -0,1225 > - 0,345 sehingga bisa dinyatakan bahwa risiko kredit dapat berfungsi sebagai variabel partial intervening dalam pengaruh Good Corporate Governance terhadap nilai perusahaan pada perusahaan perbankan yang terdaftar di Bursa Efek Indonesia periode 2011-2013.

Hasil penelitian ini menemukan bahwa pengaruh Good Corporate Governance terhadap nilai perusahaan melalui risiko kredit lebih besar pengaruhnya daripada pengaruh langsung Good Corporate Governance terhadap nilai perusahaan. Dengan demikian perusahaan perbankan di BEI dapat meningkatkan penerapan tata kelola perusahaan yang lebih baik lagi, dimana pengelolaan tata kelola yang baik akan menurunkan risiko kredit bermasalah secara tidak langsung dan dapat meningkatkan nilai perusahaan yang lebih tinggi.

\section{KESIMPULAN}

a. Good Corporate Governance mempunyai pengaruh terhadap nilai perusahaan. Hasil penelitian ini menunjukkan bahwa semakin baik tata kelola suatu perusahaan akan meningkatkan harga saham dari suatu perusahaan maka nilai perusahaan juga meningkat. Ini dikarenakan pengungkapan GCG suatu perusahaan sudah mulai membaik dan mulai mengikuti standar yang diterapkan oleh Bank Indonesia.

b. Good Corporate Governance mempunyai pengaruh terhadap risiko kredit. Hasil penelitian ini menunjukkan penerapan Good Corporate Governance yang baik dapat meminimalkan kredit bermasalah pada bank. Hal ini dikarenakan risiko kredit masuk dalam penilaian dalam kertas kerja self assessment sehingga apabila penerapan Good Corporate Governance pada bank baik maka risiko kredit juga menurun.

c. Risiko kredit mempunyai pengaruh terhadap nilai perusahaan. Hasil penelitian ini menunjukkan bahwa persentase risiko kredit yang menurun maka akan meningkatkan profitabilitas bank sehingga laba perusahaan juga meningkat serta secara langsung akan berdampak pada peningkatan nilai perusahaan. Risiko kredit juga mampu memediasi pengaruh Good Corporate Governance terhadap nilai perusahaan sehingga bisa dinyatakan bahwa risiko kredit dapat berfungsi sebagai variabel intervening dalam pengaruh Good Corporate Governance terhadap nilai perusahaan. 


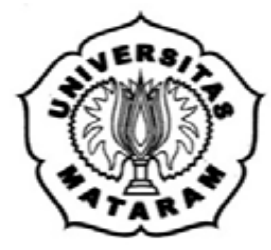

\section{SARAN}

a. Bagi perusahaan perbankan yang ada di Indonesia, hasil penelitian ini dapat dijadikan sarana dalam membenahi kebijakan perbankan terkait dengan penerapan Good Corporate Governance, risiko kredit dan nilai perusahaan. Hasil penelitian ini memberikan bukti bahwa nilai komposit Good Corporate Governance, NPL dan PBV saling berhubungan. Ketika suatu bank melakukan penerapan Good Corporate Governance yang baik maka hendaknya diikuti dengan membaiknya risiko kredit yang merupakan sumber utama pendapatan bank yang kemudian akan meningkatkan nilai perusahaan.

b. Bagi investor sebaiknya memperhatikan penerapan Good Corporate Governance yang lebih transparan sesuai dengan peratutran Bank Indonesia karena sesuai hasil penelitian Good Corporate Governance dapat mempengaruhi nilai perusahaan baik secara langsung maupun tidak langsung melalui risiko kredit.

c. Bagi peneliti selanjutnya, penelitian mengenai variabel yang dapat meningkatkan nilai perusahaan melalui sebuah atau lebih variabel intervening dapat dilakukan kembali. Penelitian ini menggunakan variabel risiko kredit sebagai variabel intervening pada pengaruh Good Corporate Governance terhadap nilai perusahaan. Pengembangan penelitian ini disarankan dengan menambah variabel intervening yang dapat mempengaruhi nilai perusahaan bank, sebagai contoh risiko likuiditas dan risiko pasar karena kedua risiko tersebut masuk dalam penilaian manajem risiko bank yang bersifat kuantitatif

\section{DAFTAR PUSTAKA}

Ali, H. Masyhud. (2006). Manajemen Risiko: Strategi Perbankkan dan Dunia Usaha Menghadapi Tantangan Globalisasi Bisnis. Jakarta : PT Rajagrafindo Persada.

Arifin, Zaenal. (2005). Teori Keuangan dan Pasar Modal. Jogjakarta : Ekonisia

Arthesa, Ade dan Edia Handiman. (2009). Bank dan Lembaga Keuangan Bukan Bank. Jakarta : PT. Indeks.

Aryani, Dwinita. (2012). Kajian Kinerja Keuangan dan Corporate Social Responsibility Terhadap Good Corporate Governance dan Nilai Perusahaan. Program Studi Manajemen STIE Malang Kucecwara.

Asian Corporate Governance Association (ACGA).2014. CG Watch 2014-Market Rangkings.

Bank Indonesia. (2008). Surat Edaran Bank Indonesia Nomor 9/12/DPNP Tanggal 30 Mei 2008 Tentang Pelaksanaan Good Corporate Governance bagi Bank Umum. Diunggah pada situs wwww.bi.go.id 


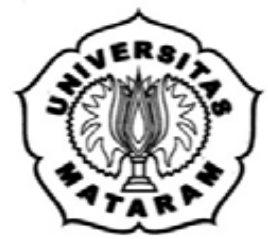

Bank Indonesia. (2011). Surat Edaran Bank Indonesia Nomor 13/6/DPNP Tanggal 18 Februari 2011 Tentang Pedoman Perhitungan Aset Tertimbang Menurut Risiko Kredit dengan Menggunakan Pendekatan Standar. Diunggah pada situs wwww.bi.go.id.

Daniri , Mas Ahmad. Good Corporate Governance :Konsep dan Penerapannya di Indonesia. Ray Indonesia, Jakarta, 2005.

Greuning, Hennie Van dan Sonja Brajovic Bratanovic. (2011). Analisis Risiko Perbankkan. Jakarta : Salemba Empat.

Hasan, Mudrika Alamsyah. (2011). Analisis Faktor yang Mempengaruhi Price To Book Value Saham. Pekbis Jurnal Vol 3, No 3, November 2011:536-548

Jensen, Michael C. dan William H. Meckling. (1976). Theory of the Firm: Managerial Behavior, Agency Cost, and Ownership Structure, Journal of Financial Economics, pp.305-360.

Julita. (2012). Pengaruh Non Performing Loan (NPL) dan Capital Adequacy Ratio Terhadap Profitabilitas (ROA) Pada Perusahaan Perbankkan Yang Terdaftar di BEI.

Kaihatu, Thomas S. (2006). Good Corporate Governance dan Penerapannya di Indonesia. Jurnal Manajemen Dan Kewirausahaan, Vol. 8, No. 1 Maret 2006:1-9.

Kawatu, F. S. (2009). Mekanisme Corporate Governance terhadap Nilai Perusahaan dengan Kualitas Laba sebagai Variabel Intervening. Jurnal Keuangan dan Perbankan, Vol. 13, No.3 : 405-417, September

Kusumadilaga, Rimba. (2010). Pengaruh Corporate Social Responsibility Terhadap Nilai Perusahaan dengan Profitabilitas Sebagai Variabel Moderating, Skripsi, Fakultas Ekonomi Diponegoro Semarang.

Larasati, A. (2009). Analisa Pengaruh Mekaisme Corporate Governance, Kualitas Laba dan Nilai Perusahaan pada Perusahaan Manufaktur yang Terdaftar di BEI. Muhidin, Sambas Ali dan Maman Abdurahman. 2011. Analisis Korelasi, Regresi, dan Jalur Dalam Penelitian. Bandung : CV Pustaka Setia.

Nursatyani, Anisa. (2011). Analisis Pengaruh Efisiensi Operasi, Risiko Kredit, Risiko Pasar, dan Modal Terhadap Kinerja Keuangan Perbankan. Skripsi. Fakultas Ekonomi Universitas Diponegoro.

Otoritas Jasa Keuangan. (2014). Roadmap Tata Kelola Perusahaan Indonesia Menuju Tata Kelola Emiten dan Perusahaan yang Lebih Baik.

Permana, Bayu Aji. (2012). Analisis Tingkat Kesehatan Bank Berdasarkan Metode CAMELS dan Metode RGEC. Fakultas Ekonomi Universitas Negeri Surabaya. 


\section{JURNAL MAGISTER MANAJEMEN UNIVERSITAS MATARAM \\ September 2016}

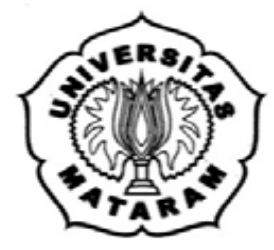

Permatasari, I., \& Novitasary, I. (2014). Pengaruh Implementasi Good Corporate Governance terhadap Permodalan dan Kinerja Perbankan di Indonesia: Manajemen Risiko sebagai Variabel Intervening. Jurnal Ekonomi Kuantitatif Terapan, 7(1), 52-59.

Purwani, Tri. (2010). Pengaruh Good Corporate Governance Terhadap Kinerja Perusahaan. Majalah Ilmiah Informatika Vol. 1 No. 2.

Putri, Ginza Angelina Purwanto. (2013). Analisis Pengaruh Kepemilikan Institusional, Free Cash Flow, Investment Opportunity Set Terhadap Nilai Perusahaan Dengan Kebijakan Hutang Sebagai Variabel Intervening. Skripsi. Fakultas Ekonomika dan Bisnis. Universitas Diponogoro.

Ratih, Ni Made Dwi Kumala. (2011). Pengaruh Risiko Kredit Terhadap Nilai Perusahaan dengan Good Corporate Governance sebagai Variabel Pemoderasi. Fakultas Ekonomi Universitas Udayana.

Retno, Reni Dyah dan Denies, Priantinah, Msi, Ak. (2012). Pengaruh Good Corporate Governance dan Pengukapan Corporate Social Responbility Terhadap Nilai Perusahaan, Jurnal Nominal/Vol 1, No 1/Tahun 2012.

Riduwan dan Engkos Achmad Kuncoro. (2012). Cara Mudah Menggunakan dan Memakai Path Analysis (Analisis Jalur). Bandung : Alfabeta.

Sari, Enggar Fibria Verdana dan Akhmad Riduwan. (2013). Pengaruh Good Corporate Governance Terhadap Nilai Perusahaan : Kualitas Laba Sebagai Variabel Intervening. Jurnal Ilmu dan Riset Akuntansi. Volume 1 Nomor 1.

Sembiring, E.R. (2005). Karakteristik Perusahaan Dan Pengungkapan Tanggung Jawab Sosial. :Studi Empiris Pada Perusahaan Yang Tercatat Di Bursa Efek Jakarta. SNA VIII Solo.

Setyawan, Aditya Wira Perdana. (2012). Pengaruh Kompenen Risk Based Bank Rating (RBBR) Terhadap Harga Saham Perusahaan Perbankan yang Go-Publik di Bursa Efek Indonesia Tahun 2008-2011. Skripsi. Fakultas Ekonomika dan Bisnis. Universtias Diponogoro.

Siallagan, Hamonngan dan Mas'ud Machfoedz. (2006). Mekanisme Corporate Governance, Kualitas Laba dan Nilai Perusahaan. Simposium Nasional Akuntansi 9 Padang.

Sugiyono. (2013). Metode Penelitian Kuantitaif, Kualitatif dan R\&D. Bandung : Alfabeta.

Suharli, Michell. (2006). Studi Empiris terhadap Faktor yang Mempengaruhi Nilai Perusahaan pada Perusahaan Go Public di Indonesia. Jurnal Maksi, Volume 6 Nomor 1. Januari : 23-41. 


\section{JURNAL MAGISTER MANAJEMEN UNIVERSITAS MATARAM \\ September 2016}

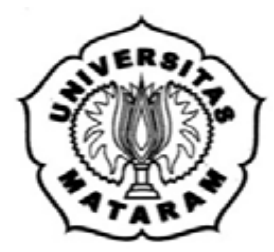

Tertius, Melia Agustina dan Yulius Jogi Christiawan. (2015). Pengaruh Good Corporate Governance Terhadap Kinerja Perusahaan Pada Sektor Keuangan. Business Acounting Review Vol. 3 No. 1. 223-232.

Ujiyantho, M. A. dan B. A. Pramuka. (2007). Mekanisme Corporate Governance, Manajemen Laba dan Kinerja Keuangan. Simposium Nasional Akuntansi X.

$\underline{w w w . b i . g o . i d}$

$\underline{w w w . i d x . c o . i d}$ 